\title{
GROWTH FEATURES OF MYCOBACTERIUM LEPRAEMURIUM CULTIVATED IN NC-5 MEDIUM
}

\author{
ZENSAKU YOSHII AND MASAHIRO NAKAMURA \\ Department of Microbiology, Yamaguchi University School of Medicine, \\ Ube, 755, and Kurume University School of Medicine, Kurume, 830, \\ Japan
}

(Received for publication April 30, 1975)

\begin{abstract}
Morphological features of Mycobacterium lepraemurium cultivated on a slide glass in a cell-free liquid medium, NC-5, were precisely observed by a scanning electron microscope. As previously demonstrated, elongation of bacterial cell was noted in the second weeks of cultivation, and thereafter septum formation, division, budding and branching followed. It was obvious that the growth grade of bacilli depended upon the number of bacilli presented on the slide glass; when a small number of bacilli was inoculated on the slide glass, a micro-colony was formed in 10 weeks' cultivation, but further development did not occur even if cultivation was continued.
\end{abstract}

In the previous papers ${ }^{1) 2}$, it was described that a cell-free liquid medium for Mycobacterium ( $M$ ) lepraemurium which hitherto had been thought to be an obligate intracellular parasite, was established. That the growth of bacilli in this medium is the genuine multiplication of $M$. lepraemurium in vitro, was confirmed by Dhople and Hanks ${ }^{3}$. Growth features of bacilli in this medium were selected and illustrated in the previous papers ${ }^{4)}{ }^{5}$.

The purpose of this paper is to describe all of the features of bacilli periodically observed by a scanning electron microscope between zero time and twelveth weeks of cultivation.

\section{MATERIALS AND METHODS}

\section{Bacterial strain}

M. lepraemurium (M-56), Hawaiian strain which has been maintained in
Nakamura's laboratory for several years by subcutaneous inoculation to $\mathrm{C}_{3} \mathrm{H}$ mice.

\section{Cultivation}

An experimentally developed leproma was excised under sterile condition and a bacillary suspension prepared with sterile distilled water. Tissue fragments and large bacillary clumps were removed by centrifuging at $117 \mathrm{~g}$ for $5 \mathrm{~min}$. A suspension of bacilli was prepared in sterile distilled water containing $0.1 \%$ bovine albumin $\mathrm{V}$ fraction (Armour Laboratories). A drop of the final suspension was smeared on a half-size glass slide, cut lengthwise and coated with silicone. After drying, the smeared slide was immediately placed in the culture medium (NC-5 medium) and incubated at $30^{\circ} \mathrm{C}$. Detailed descriptions of the technical procedures of cultivation have been described in the previous papers ${ }^{1 / 2}$. 


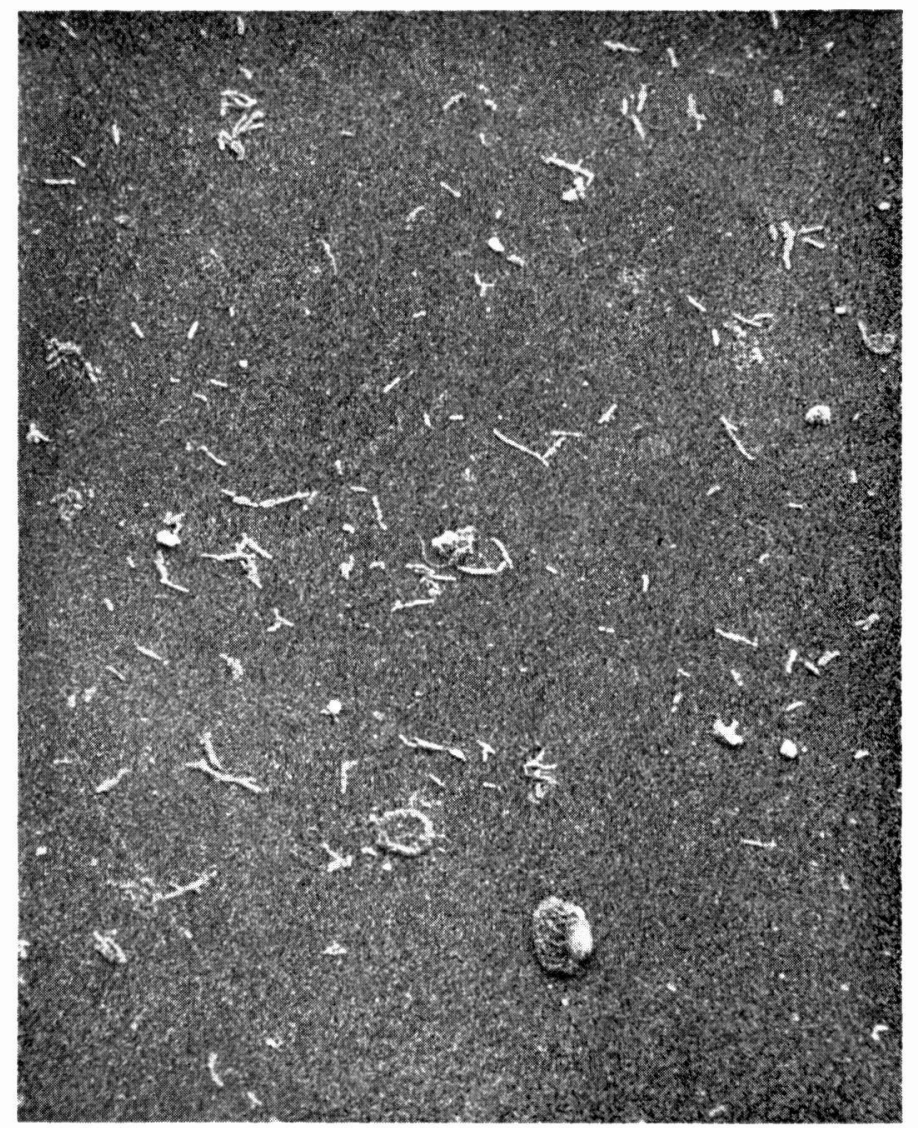

Fig. 1 Scanning electron microscopy of the central area of the smear at zero time $(1,000 \times$ magnification $)$.

The incubated slides were taken out of the culture tubes and examined at 0,2 , $4,6,8,10$ and 12 weeks.

\section{Scanning electron microscopy}

Each cultured slide was prewashed three times with phosphate buffered saline, fixed in $2.0 \%$ glutaraldehyde solution at $4{ }^{\circ} \mathrm{C}$ for $24 \mathrm{~h}$, postwashed three times with phosphate buffered saline, dehydrated through acetone solutions $(50,70,90,95,99$ and $100 \%$ in water), and finally air dried at room temperature. The parts of the slide with bacteria were cut into small pieces, about $8 \times 8 \mathrm{~mm}$, and coated by carbongold evaporation. They were viewed using JSM - S 1 and JSM - U 3 scanning electron microscopes (Japan Electron Optics Laboratory, Japan) at 10 and 15 $\mathrm{kV}$ respectively.

\section{RESULTS}

Growth features of M. lepraemurium located at the central area of the smear 


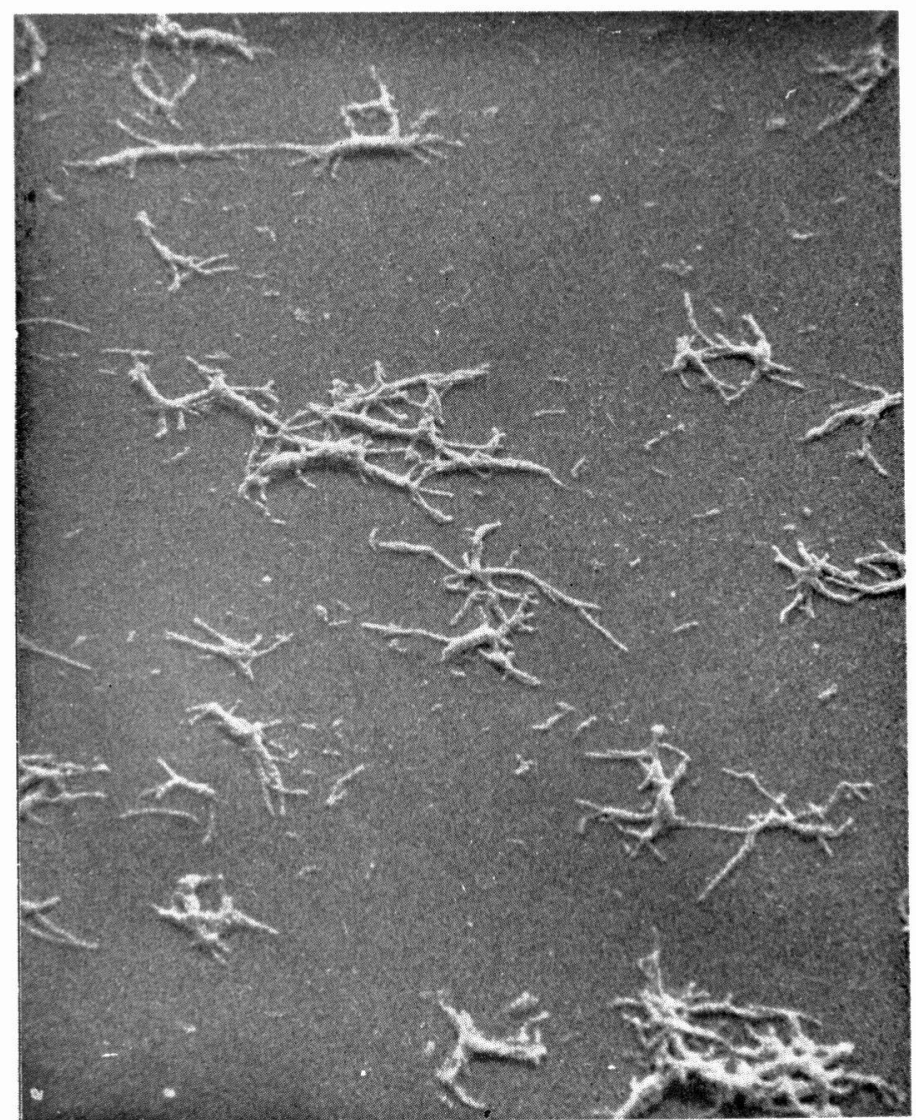

Fig. 2 Scanning electron microscopy of the central area of the smear at 8 weeks after cultivation at $30{ }^{\circ} \mathrm{C}$ $(1,000 \times$ magnification $)$.

Growth features of $M$. lepraemurium in the course of multiplication from zero time to twelveth weeks of cultivation in the $\mathrm{NC}-5$ medium at $30^{\circ} \mathrm{C}$, were loosely observed by lowely mag*nified scanning electron microscopy. As shown in Fig. 1 to 4 , it is demonstrated that bacterial cells located at the central area of the smear were separately distributed and that the growth started from an individual cell. Although a microcolony formation was completed at 8 weeks after cultivation, no further development occurred, even if cultivation was continued.

Highly magnified scanning electron micrographs reveal more precisely developing features of bacilli as illustrated in Fig. 5 to 12 . Fig. 5 shows the starting material, in which bacterial cells were well distributed. There were various forms; ones might be solid and others segmented. Fig. 6 is a micrograph at two weeks after cultivation ; it is obvious that the growth already started, that is, there are some cells 


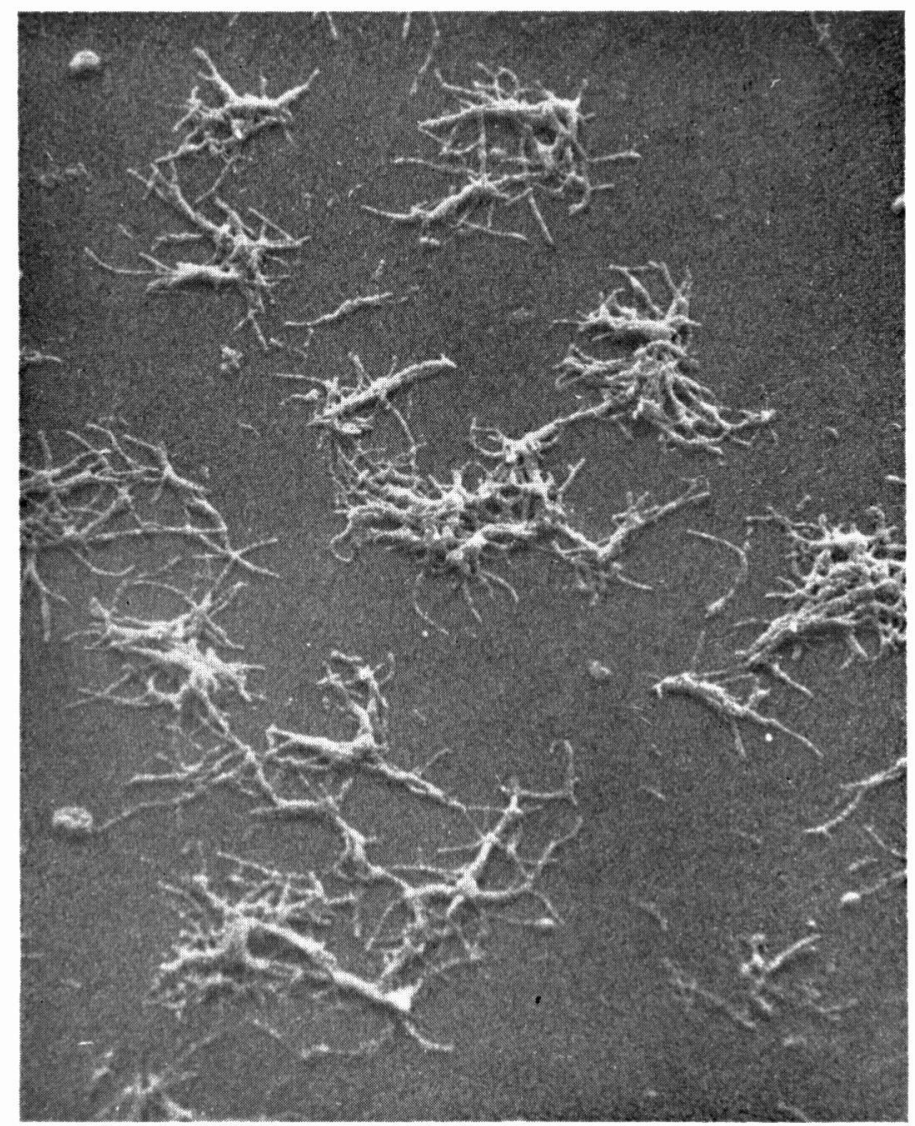

Fig. 3 Scanning electron microscopy of the central area of the smear at 10 weeks after cultivation at $30^{\circ} \mathrm{C}$ $(1,000 \times$ magnification $)$.

which elongated and branched after budding. Fig. 7 is a highly magnified $(9,000 \times)$ scanning electron micrograph in which indicated a dividing after elongation.

The beginning stage of a microcolony after branching with budding was shown in Fig. 8, taken at the 6 th weeks of cultivation. Fig. 9 and 10 indicated that a microcolony was formed with about 10 cells. Fig. 11 shows a part of microcolony which was partially magnified.
In the figure, it is demonstrated that there were a pattern of over growth and an appearance of a large granule at the assembly site of cells.

In the last figure, Fig. 12 taken at the 14 th weeks of cultivation, there was a lot of granulated cells which might be a degenerative sign. Therefore, it should be presumed that the growth of $M$. lepraemurium in the $\mathrm{NC}-5$ medium would cease at the 12 th weeks after cultivation. 


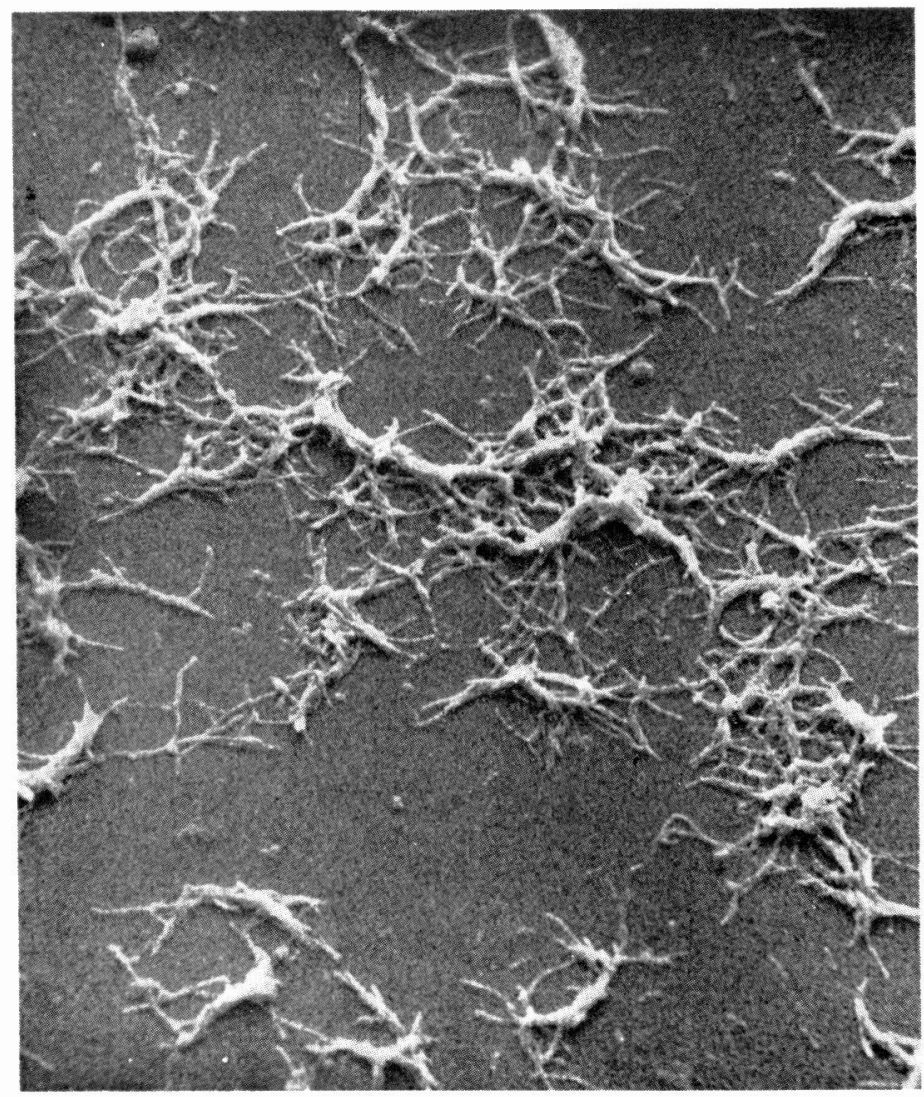

Fig. 4 Scanning electron microscopy of the central area of the smear at 12 weeks after cultivation at $30^{\circ} \mathrm{C}$ $(1,000 \times$ magnification $)$.

Growth features of M. lepraemurium located at the peripheral area of the smear

Unlikely the features at the central area of the smear, there was a large number of bacterial cells at the peripheral area of the smear as shown in Fig. 13. The course of the growth of $M$. lepraemurium at the peripheral area were illustrated in Fig. 14 to 20 . As well known common phenomenon, when a large number of cells was presented, the growth rate was increased. However, the growth patterns at the peripheral area were almost the same as observed at that of central area, except a rapid growth and a rapid regression. As shown in Fig. 16 to 18, the growth had continued on the lawn of regressive cells, but finally regressive forms had appeared from the 12 th weeks of cultivation (Fig. 19). At the 14 th weeks (Fig. 20), most of cells became to be regressive. 


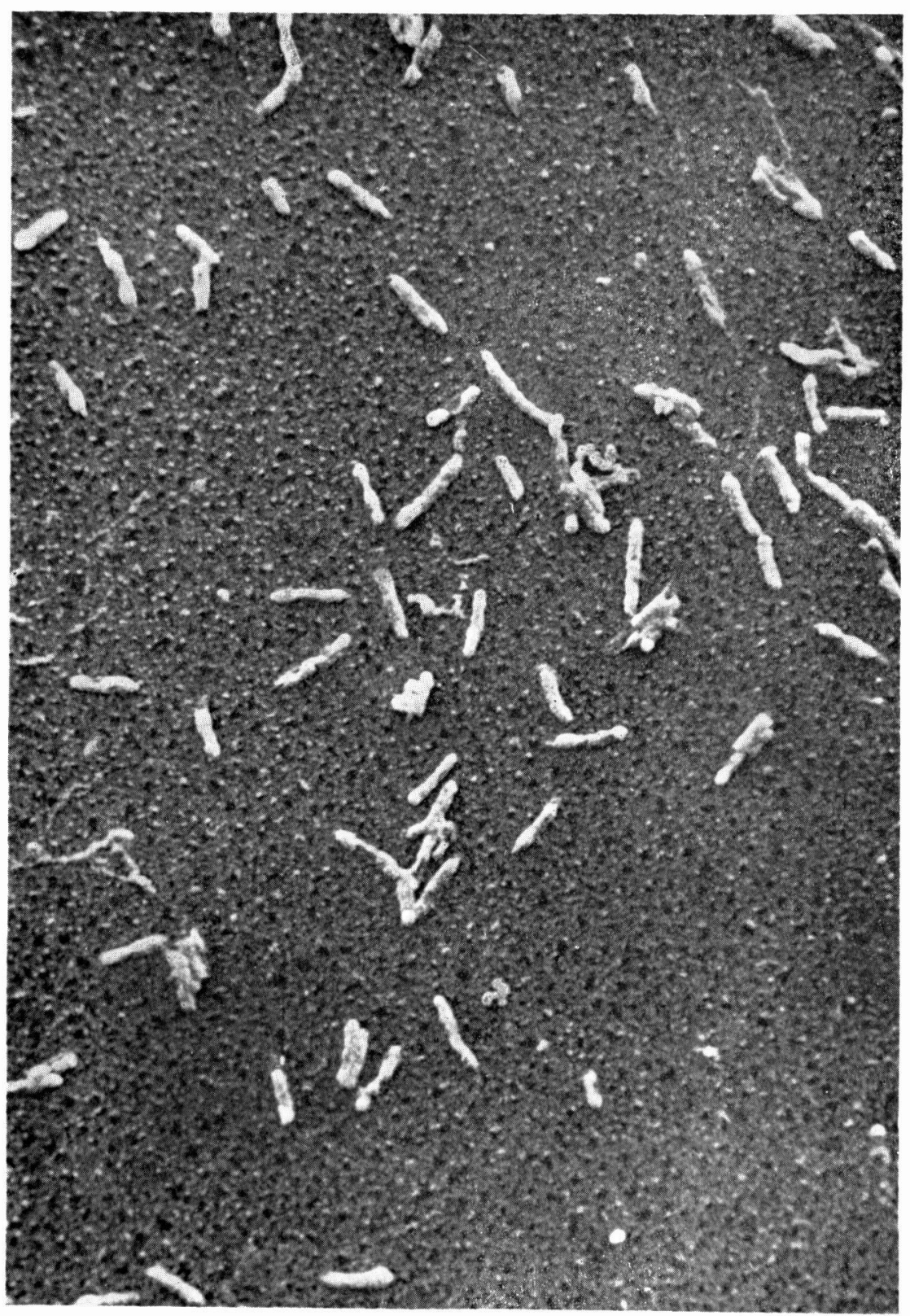

Fig. 5 Scanning electron microscopy of the central area of the smear at zero time $(4,500 \times$ magnification $)$. 


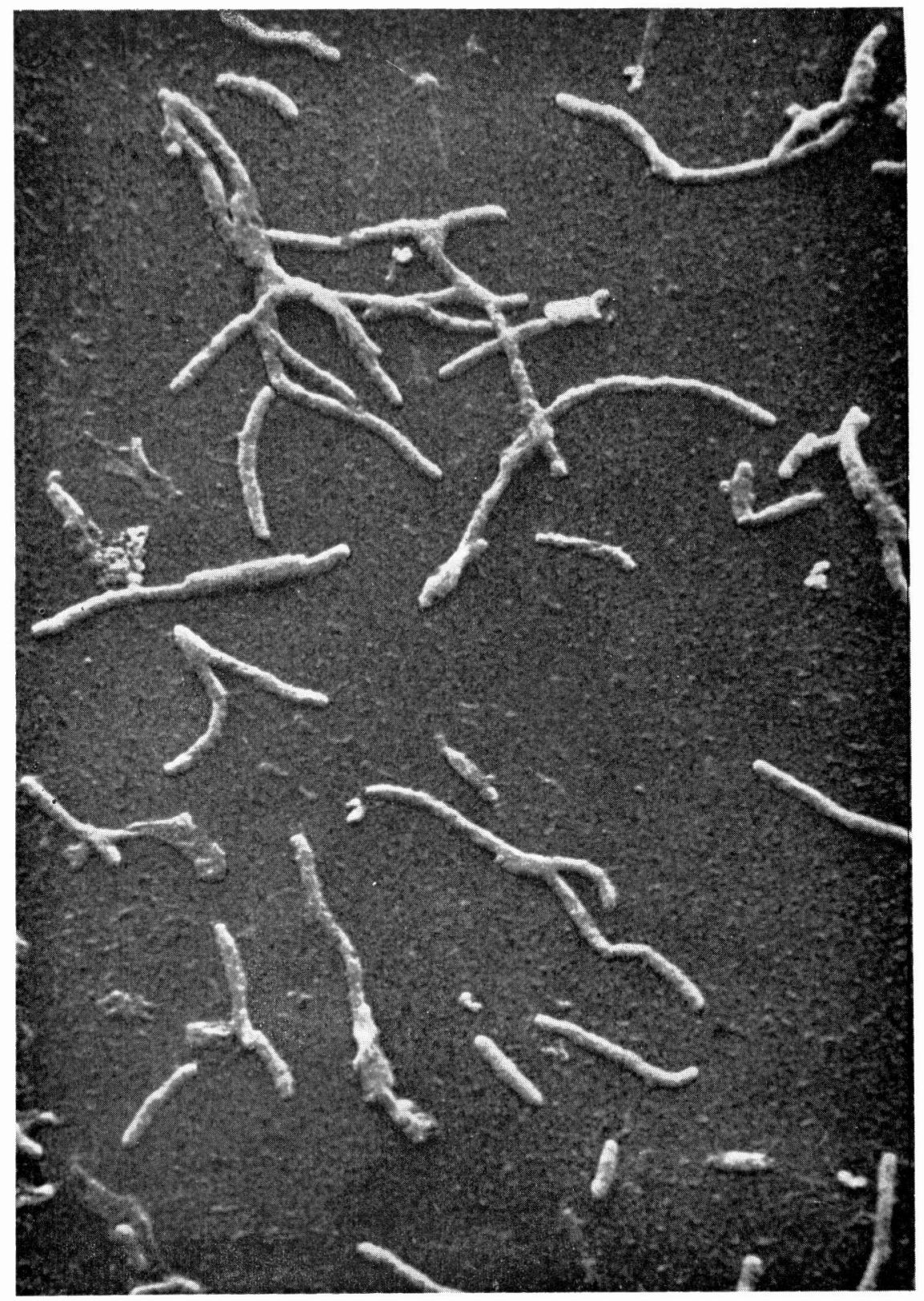

Fig. 6 Scanning electron microscopy of the central area of the smear at 2 weeks after cultivation at $30{ }^{\circ} \mathrm{C}$ $(4,500 \times$ magnification $)$. 


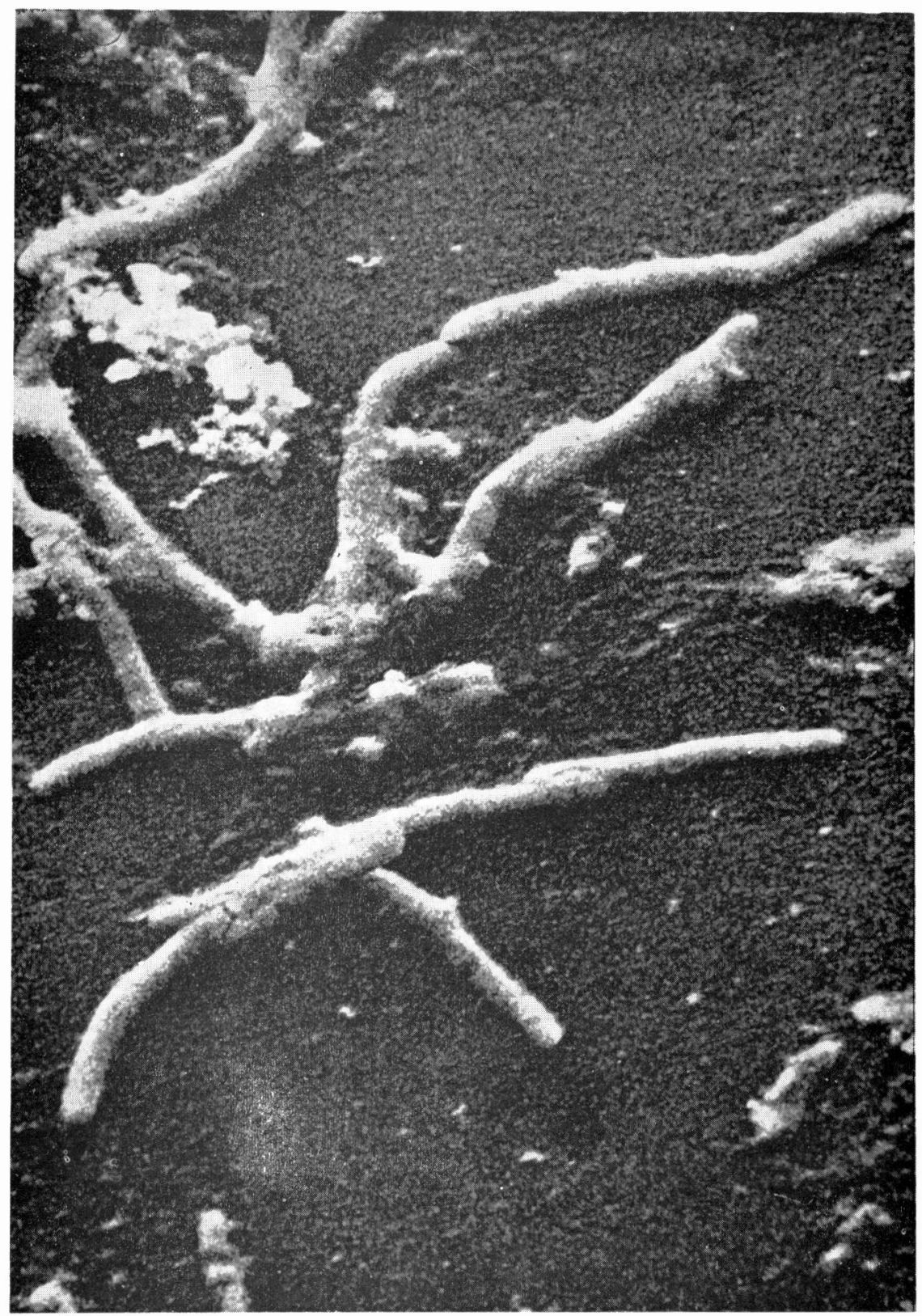

Fig. 7 Scanning electron microscopy of the central area of the smear at 4 weeks after cultivation at $30^{\circ} \mathrm{C}$ $(9,000 \times$ magnification $)$. 


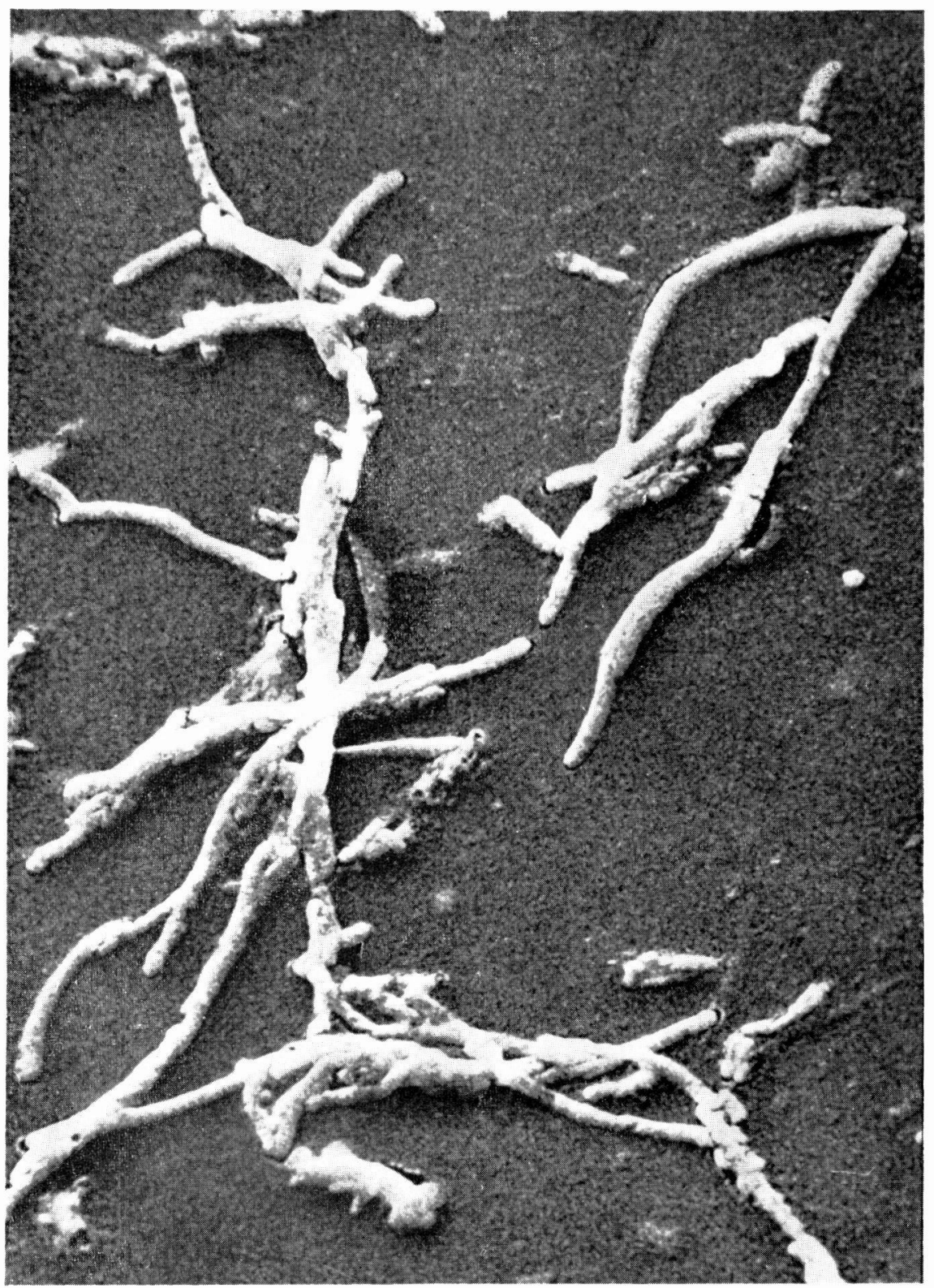

Fig. 8 Scanning electron microscopy of the central area of the smear at 6 weeks after cultivation at $30^{\circ} \mathrm{C}$ $(4,500 \times$ magnification $)$. 


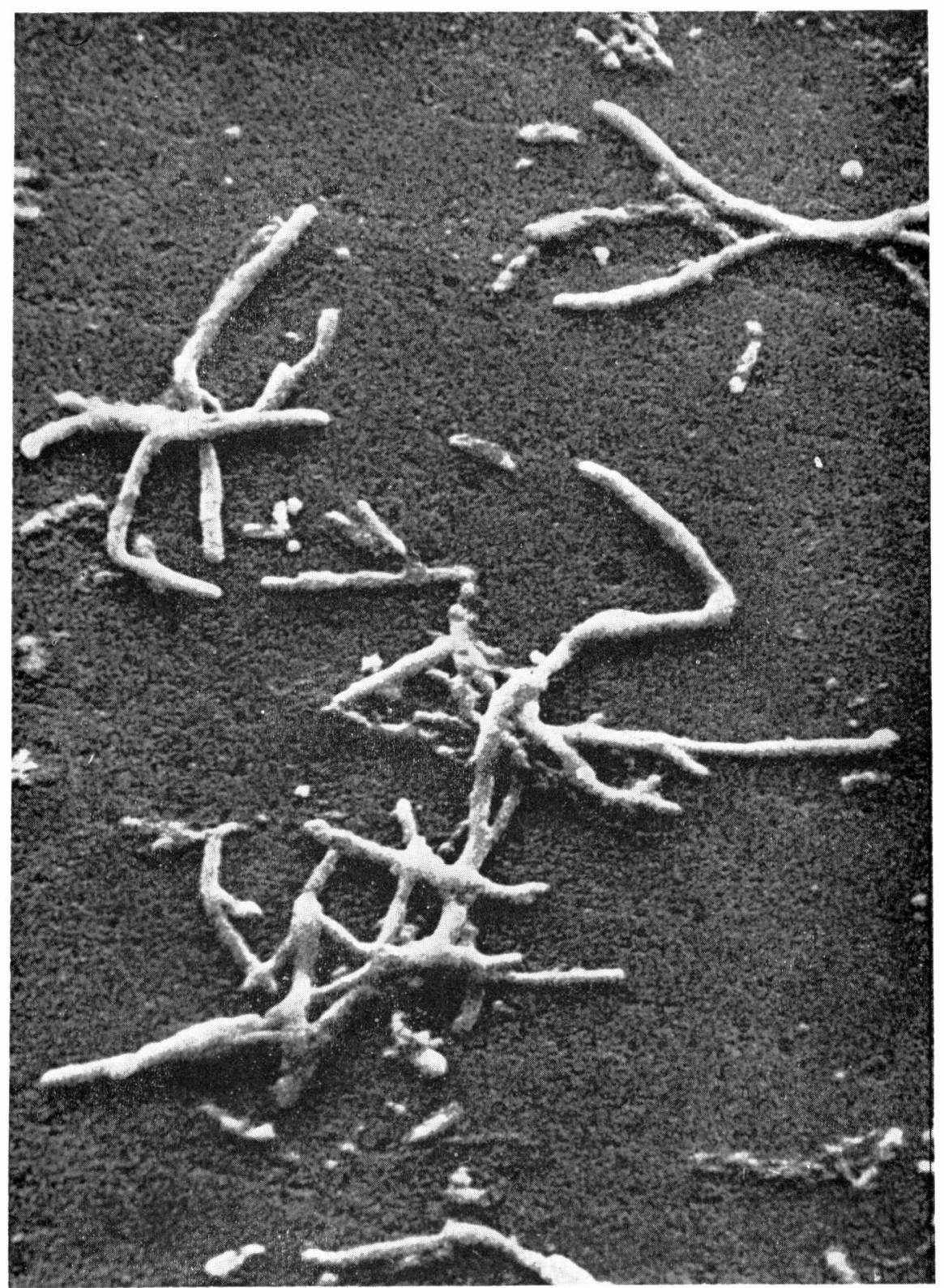

Fig. 9 Scanning electron microscopy of the central area of the smear at 8 weeks after cultivation at $30{ }^{\circ} \mathrm{C}$ $(4,500 \times$ magnification $)$. 


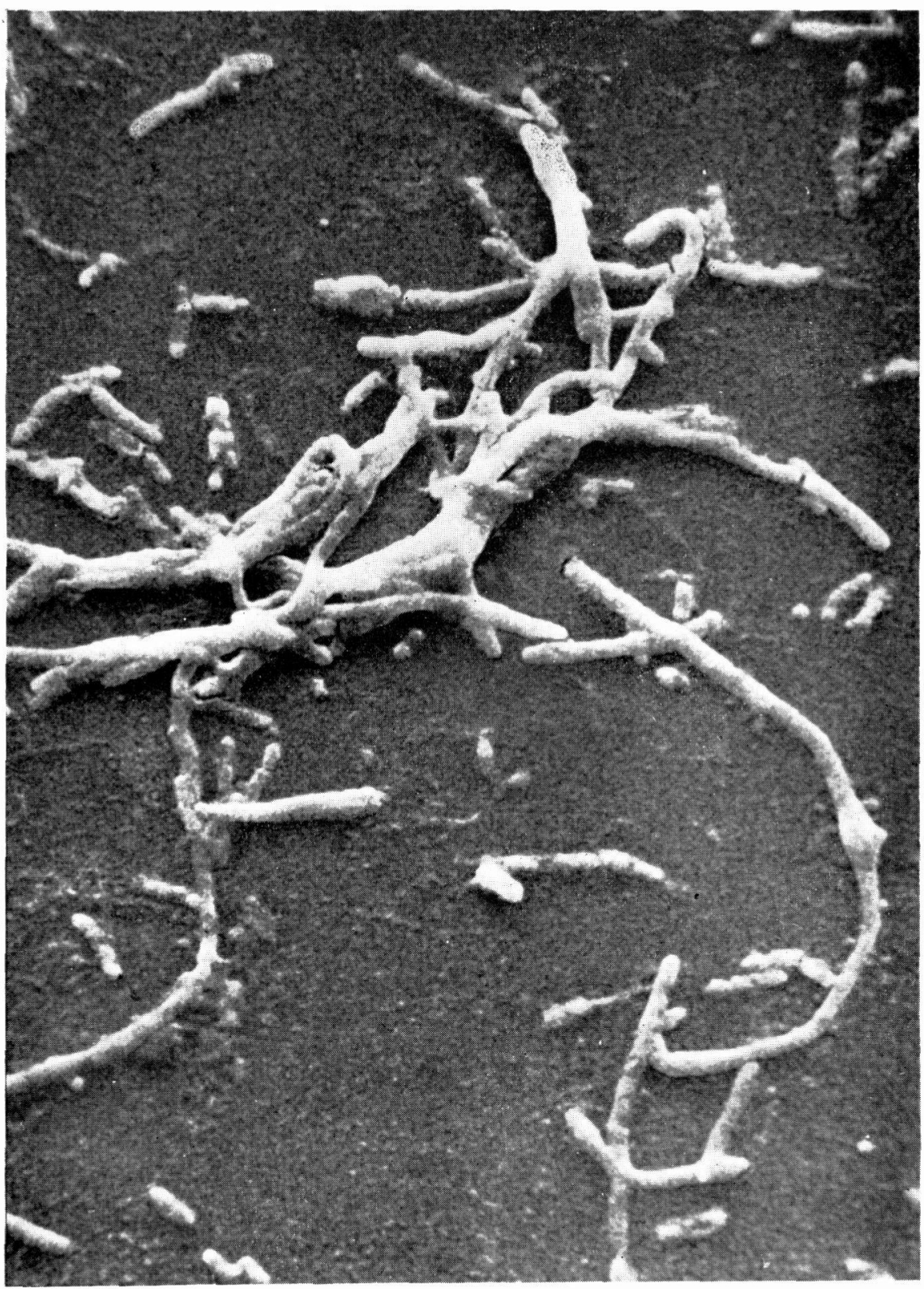

Fig. 10 Scanning electron microscopy of the central area of the smear at 10 weeks after cultivation at $30{ }^{\circ} \mathrm{C}$ $(4,500 \times$ magnification $)$. 


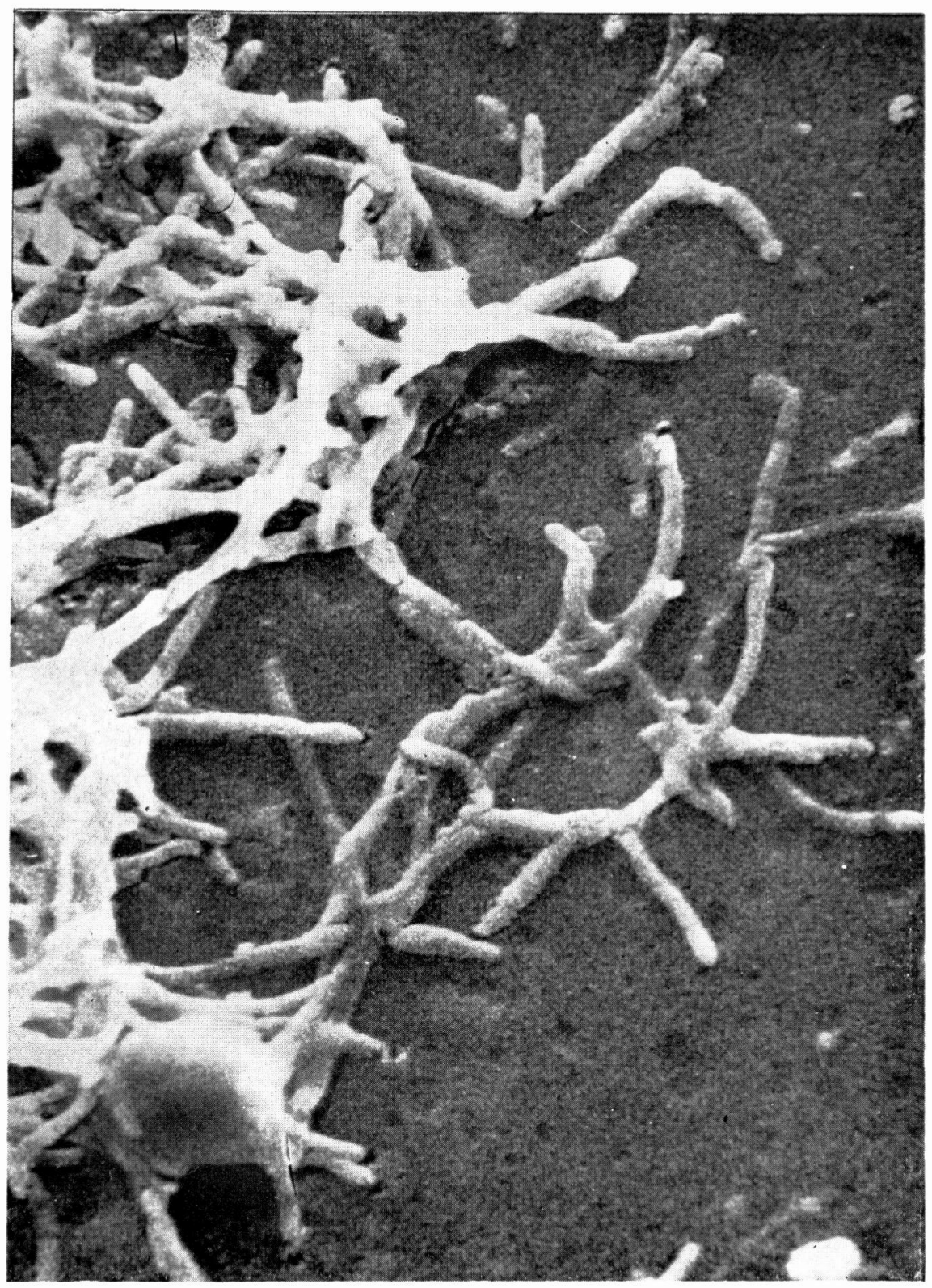

Fig. 11 Scanning electron microscopy of the central area of the smear at 12 weeks after cultivation at $30{ }^{\circ} \mathrm{C}$ $(4,500 \times$ magnification $)$. 


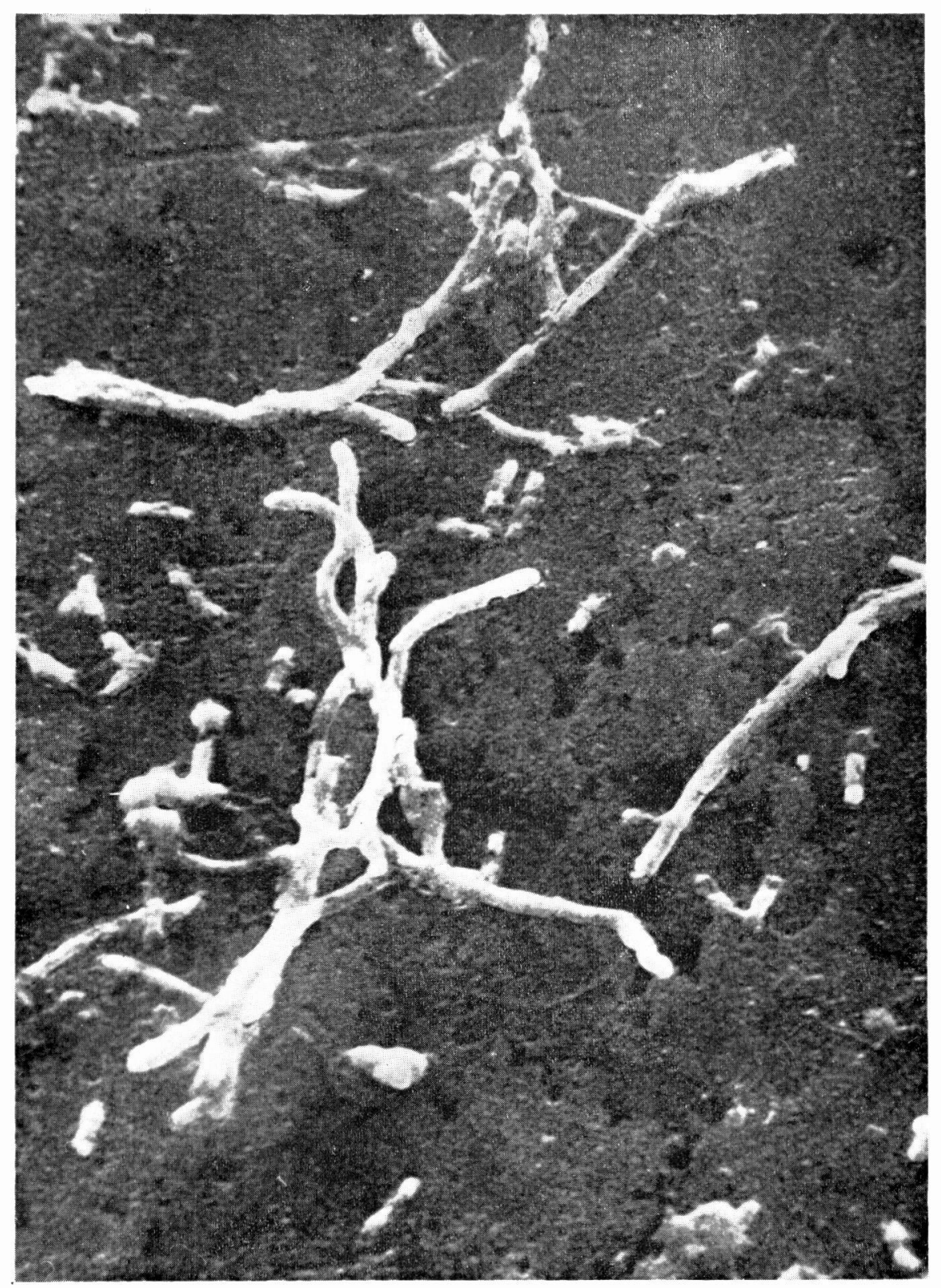

Fig. 12 Scanning electron microscopy of the central area of the smear at 14 weeks after cultivation at $30^{\circ} \mathrm{C}$ $(4,500 \times$ magnification $)$. 


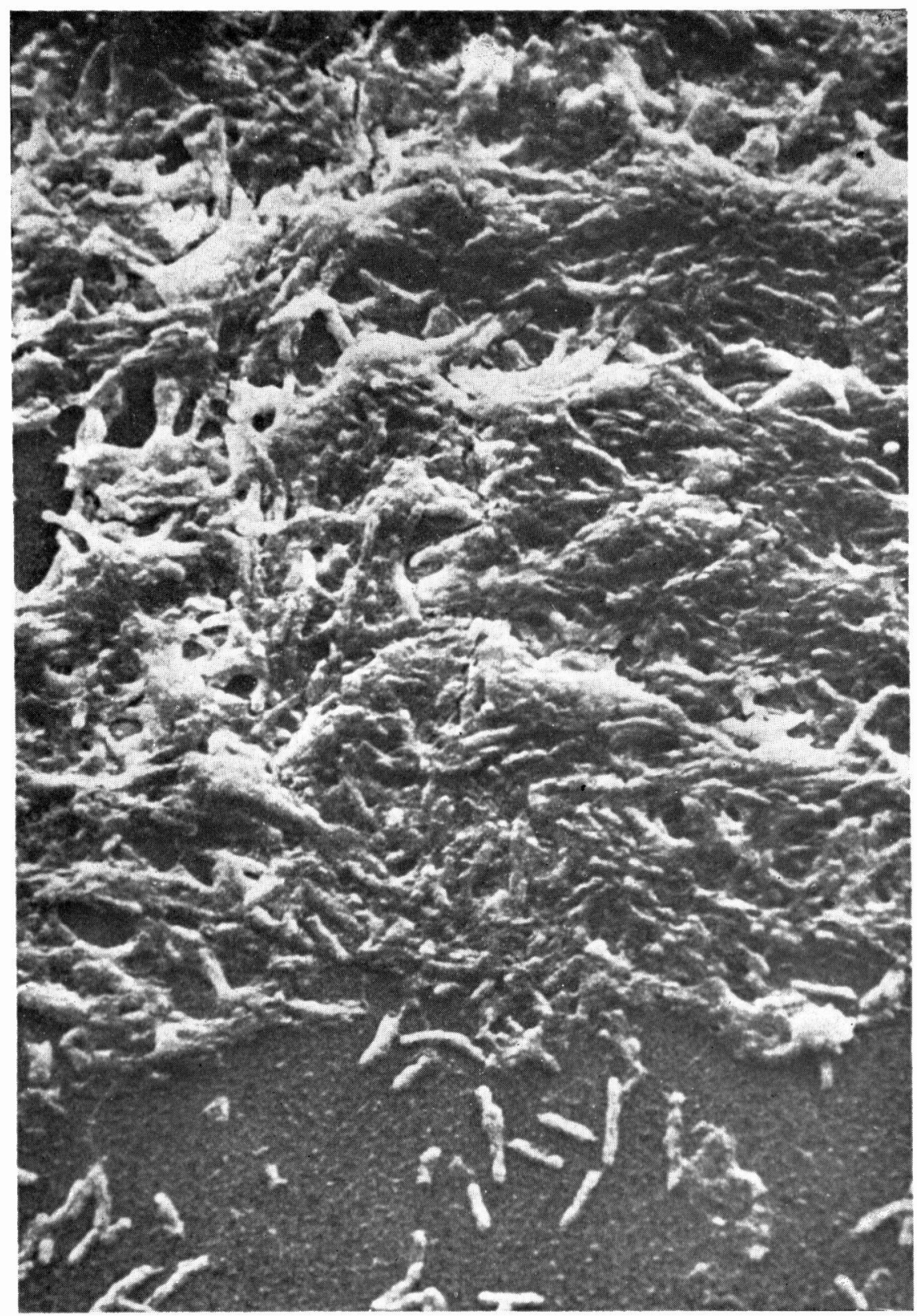

Fig. 13 Scanning electron microscopy of the peripheral area of the smear at zero time $(4,500 \times$ magnification $)$. 


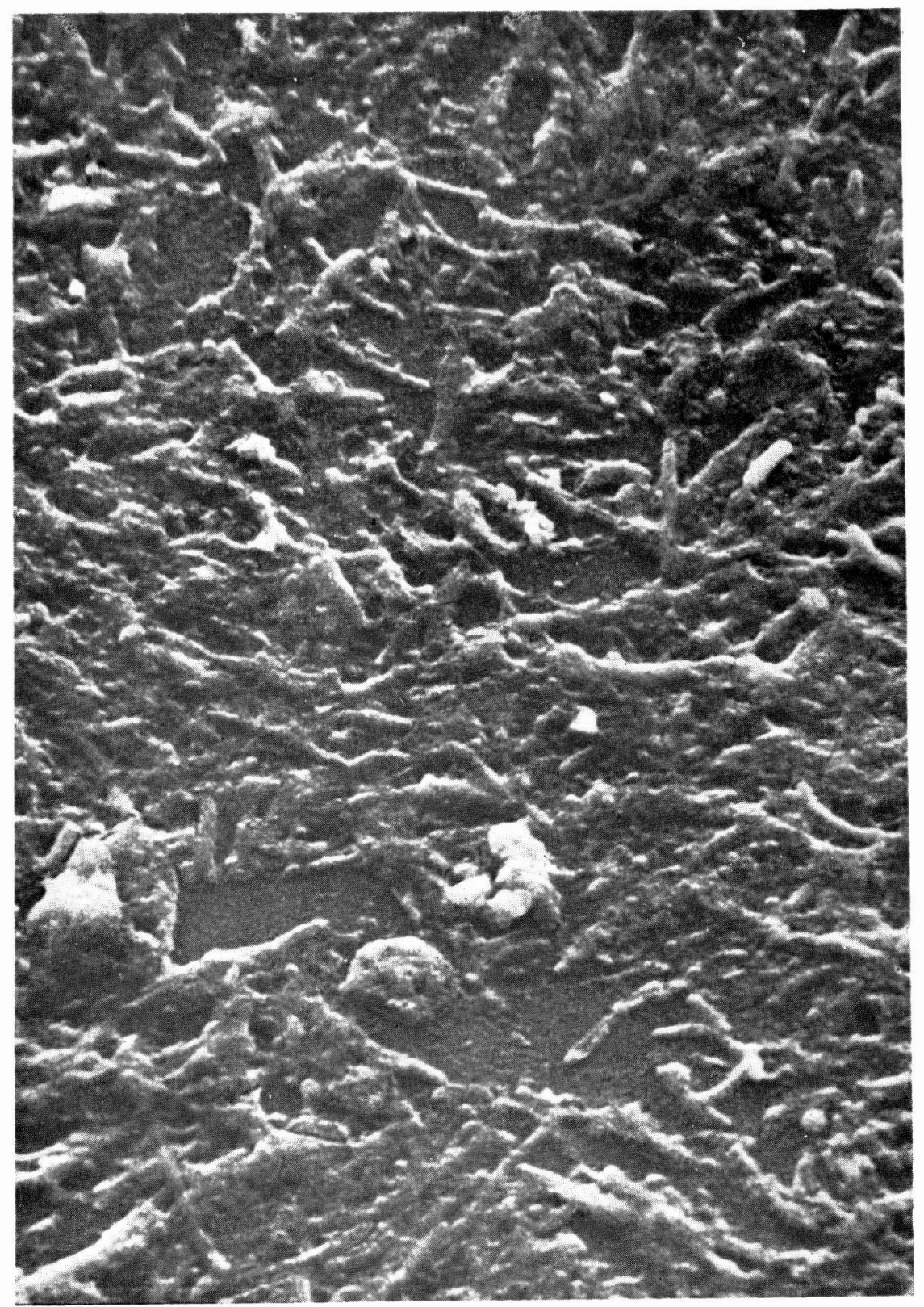

Fig. 14 Scanning electron microscopy of the peripheral area of the smear at 2 weeks after cultivation at $30^{\circ} \mathrm{C}$ $(4,500 \times$ magnification $)$. 


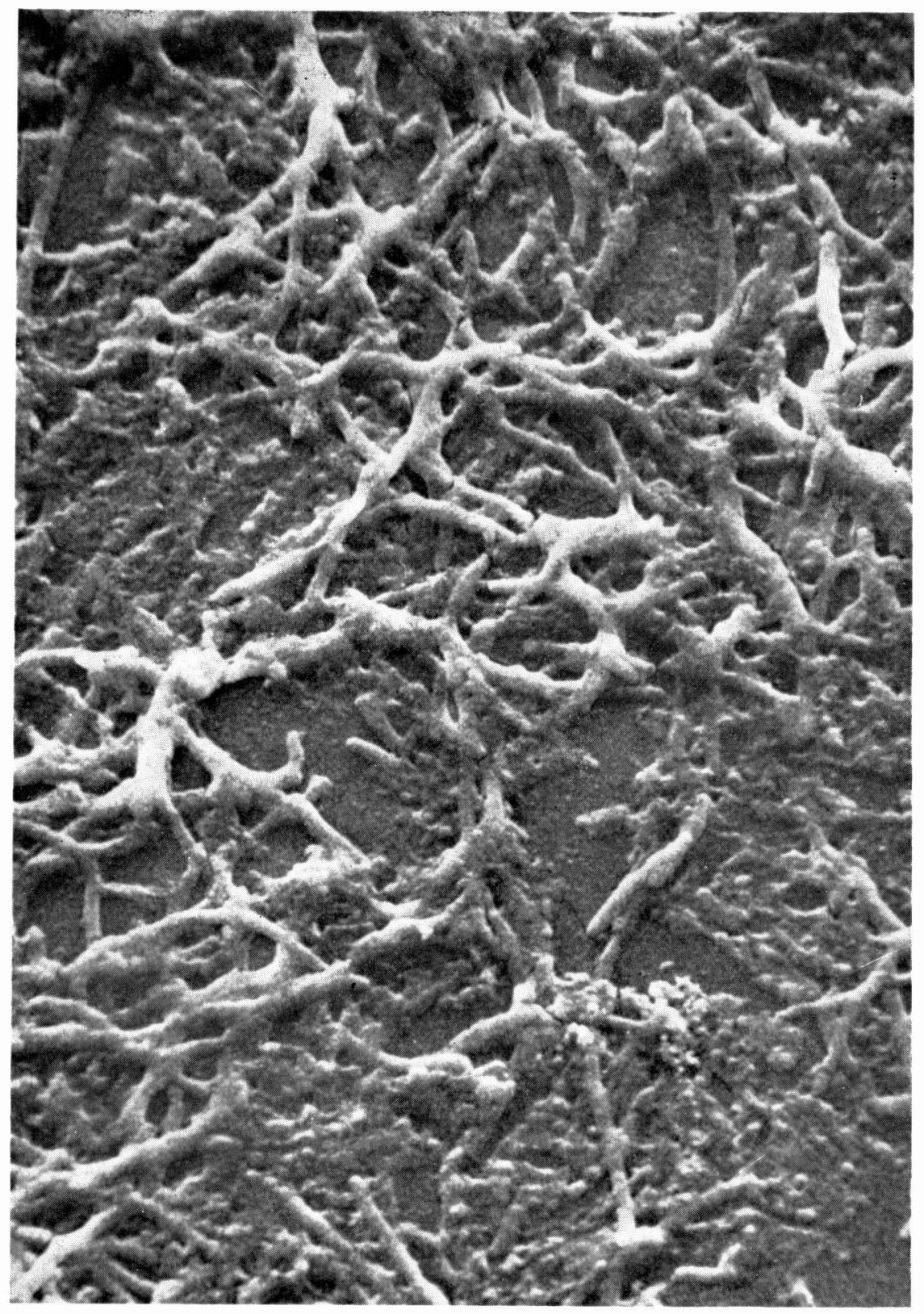

Fig. 15 Scanning electron microscopy of the peripheral area of the smear at 4 weeks after cultivation at $30^{\circ} \mathrm{C}$ $(4,500 \times$ magnification $)$. 


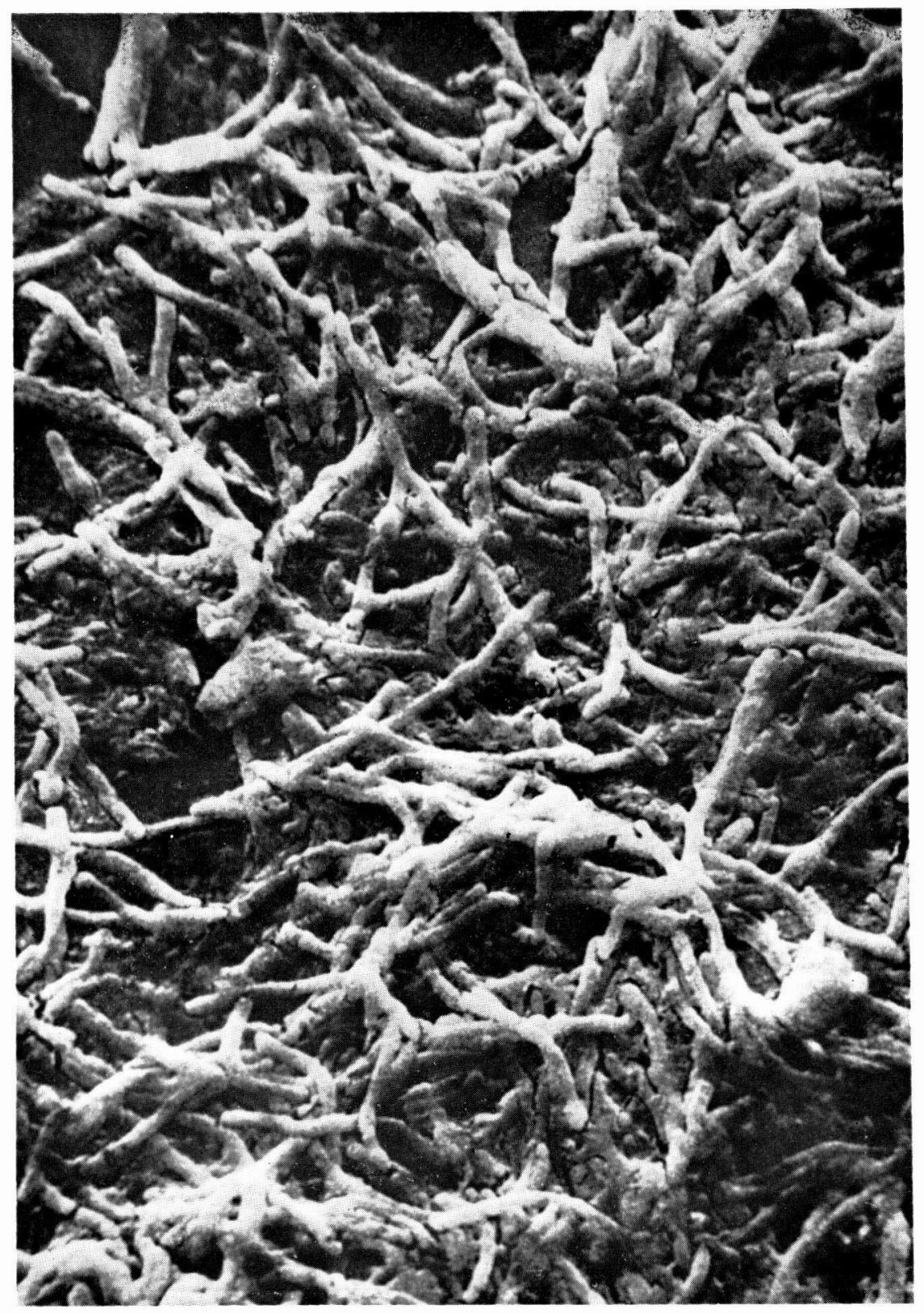

Fig. 16 Scanning electron microscopy of the peripheral area of the smear at 6 weeks after cultivation at $30{ }^{\circ} \mathrm{C}$ $(4,500 \times$ magnification $)$. 


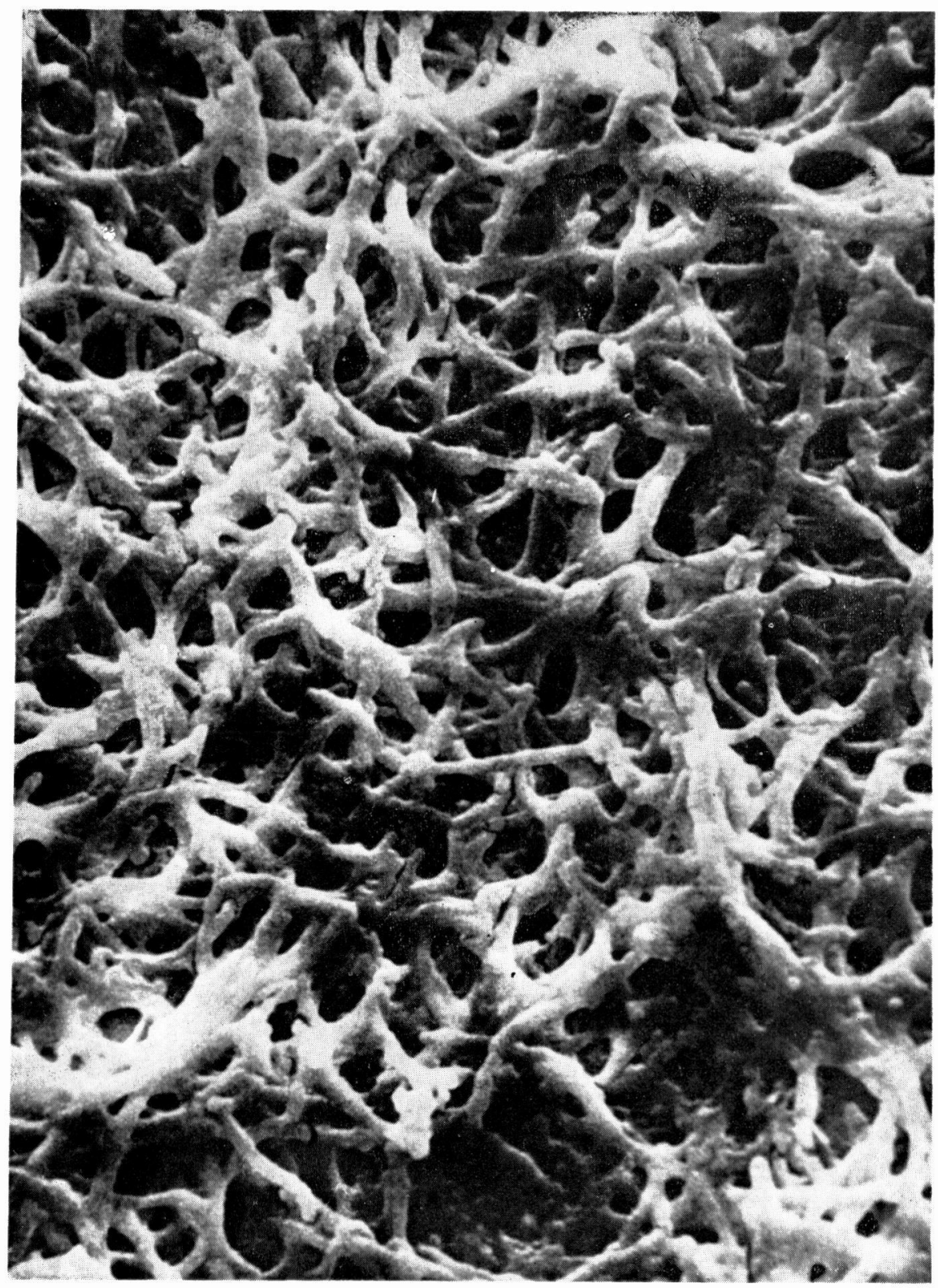

Fig. 17 Scanning electron microscopy of the peripheral area of the smear at 8 weeks after cultivation at $30^{\circ} \mathrm{C}$ $(4,500 \times$ magnification $)$. 


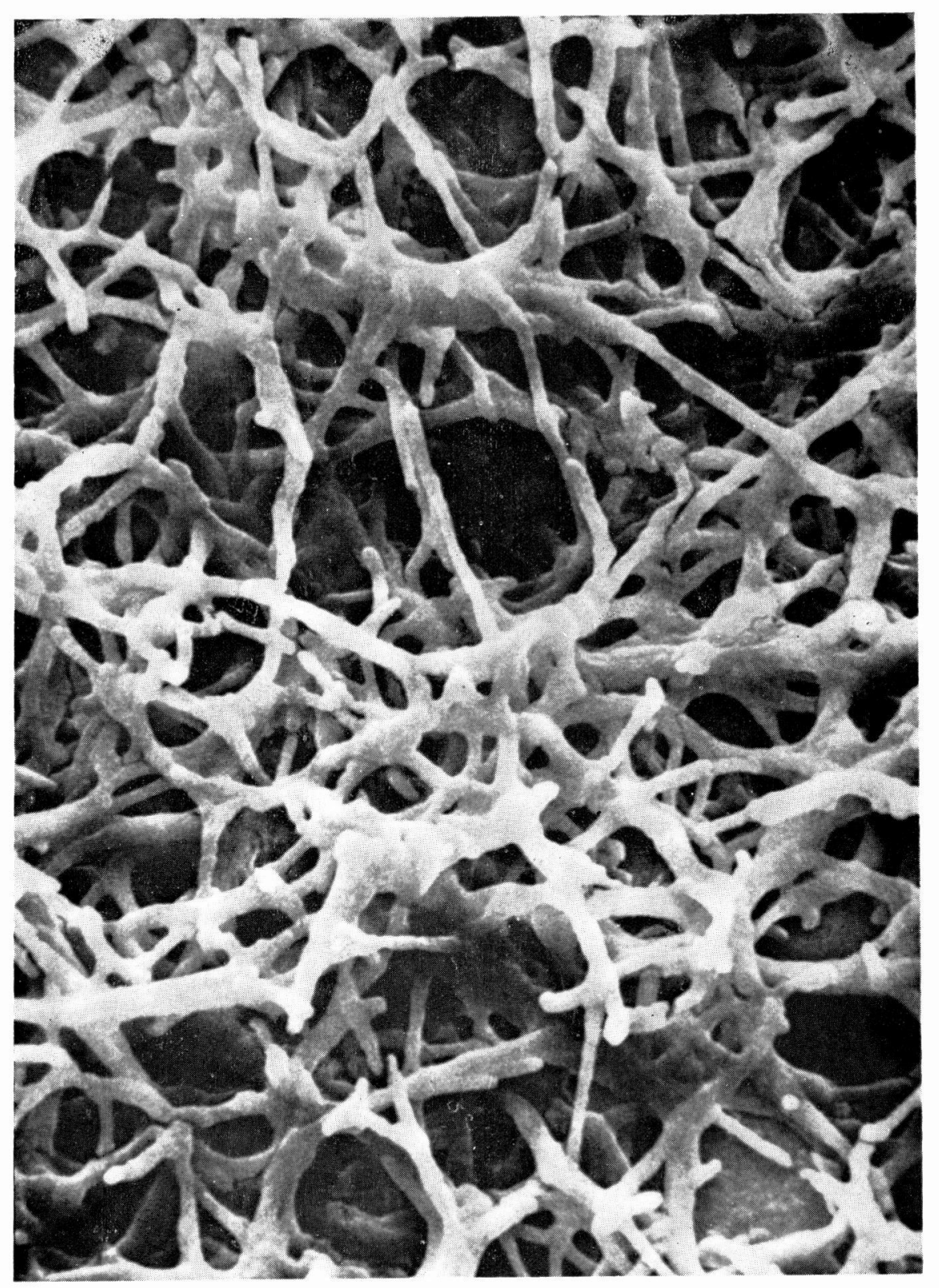

Fig. 18 Scanning electron microscopy of the peripheral area of the smear at 10 weeks after cultivation at $30^{\circ} \mathrm{C}$ $(4,500 \times$ magnification $)$. 


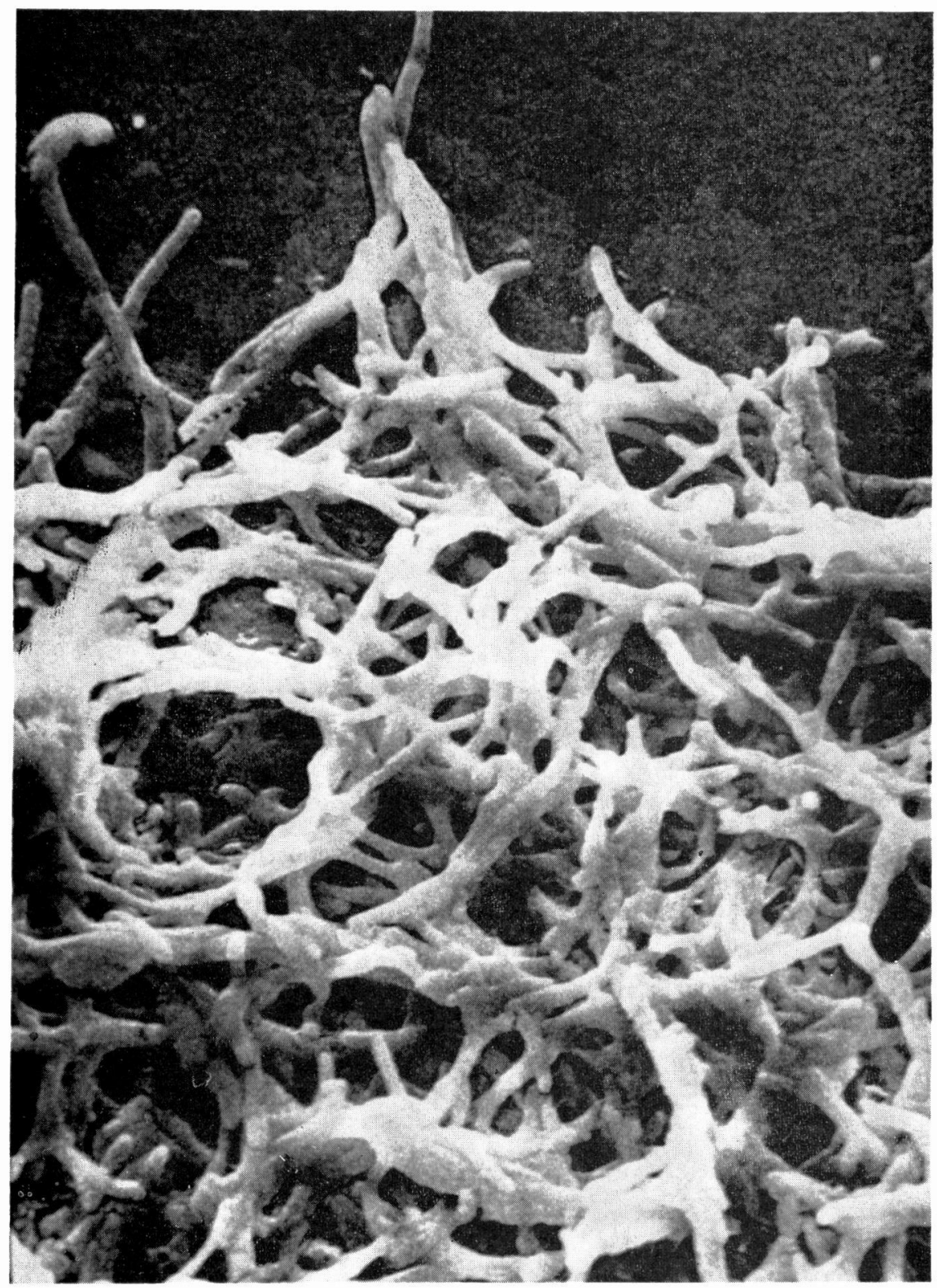

Fig. 19 Scanning electron microscopy of the peripheral area of the smear at 12 weeks after cultivation at $30^{\circ} \mathrm{C}$ $(4,500 \times$ magnification $)$. 


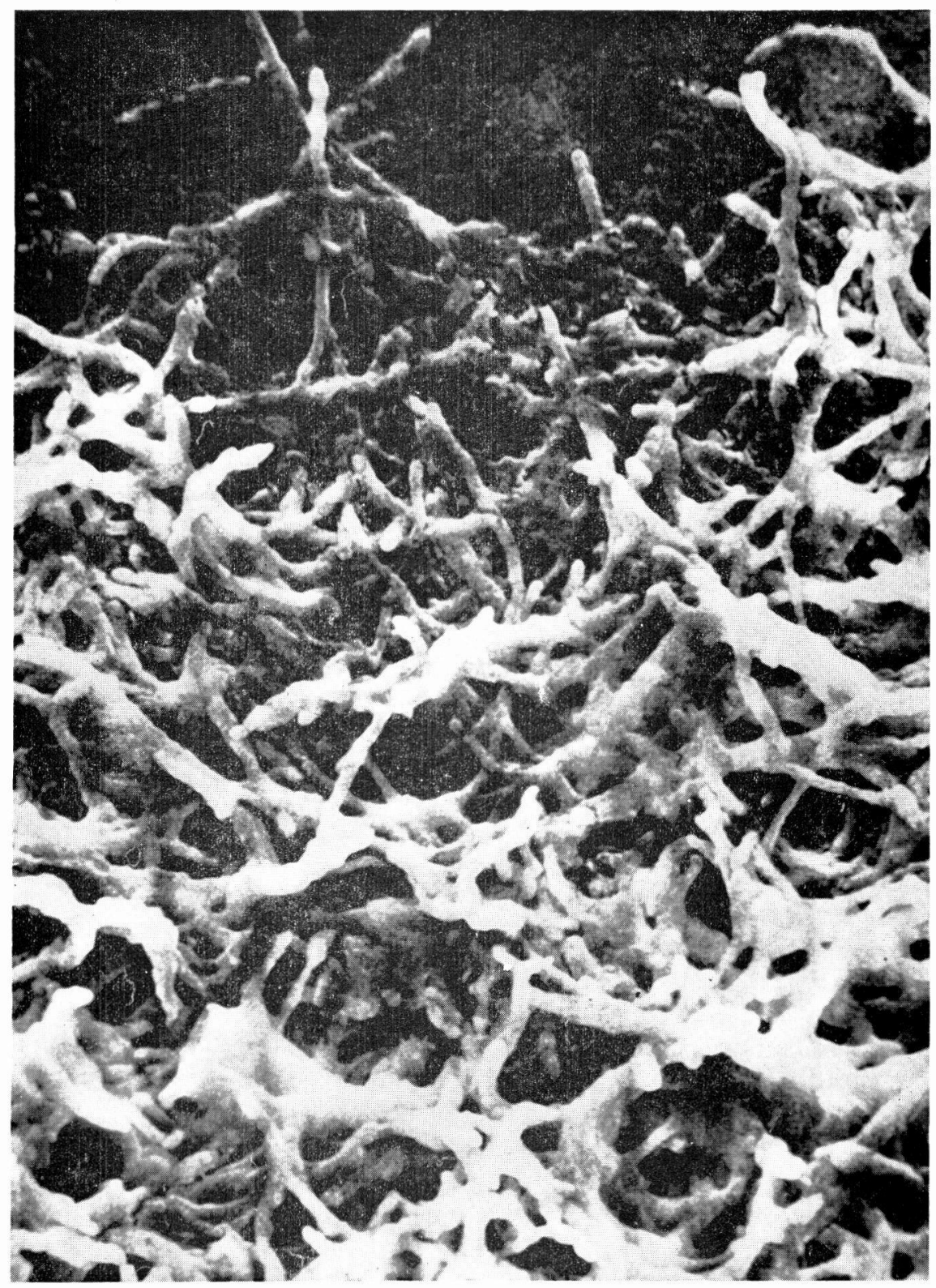

Fig. 20 Scanning electron microscopy of the peripheral area of the smear at 14 weeks after cultivation at $30^{\circ} \mathrm{C}$ $(4,500 \times$ magnification $)$. 


\section{DISCUSSION}

There is no report concerning the growth feature of $M$. lepraemurium and $M$. leprae in vitro without cells, because no appropriate culture method of these organisms has been established.

In 1973, a cell-free liquid culture medium for multiplication of $M$. lepraemurium was established by Nakamura ${ }^{11}$ This culture medium is very suitable for quantitative measurement of the increase of the number of bacterial cells and for observing the growth pattern when the slide culture method was employed. By means of this method, general informations of the growth of $M$. lepraemurium in vitro which hitherto is thought to be an intracellular parasite, and a mode of the growth of individual celi were described ${ }^{4)}$ 6).

In the present paper, more detail features about the growth pattern taken by a scanning electron microscope were demonstrated.

The results obtained indicate that there is no difference between the growth pattern of $M$. lepraemurium and that of other culturable mycobacterium, and that the growth of $M$. lepraemurium stopped at the 12th weeks after cultivation under the condition employed here. The latter should strongly suggest that no possibility of subcultivation of the bacilli under the same condition used for a primary cultivation might be noted.

In the future, inside fine structures of cultivated cell should be observed by a ultra-thin section method, because a relationship between the surface struc- ture observed by scanning electron microscopy and the inside changes in the growing cells should provide an important information for subculturing $M$. lepraemurium and a primary culture attempt of $M$. leprae.

\section{ACKNOWLEDGEMENT}

This work was partially aided by a grant from the US-Japan Cooperative Medical Science Program.

\section{REFERENCES}

1) Nakamura, M.: Multiplication of Mycobacterium lepraemurium in a cell free liquid medium. Proc. Jap. Acad., 49, 42-46, 1973.

2) Nakamura, M.: Quantitative multiplication of Mycobacterium lepraemurium in a cell-free liquid medium (NC-5). J. Gen . Microbiol, 82, 385-391, 1974.

3 ) Dhople, A. M. and Hanks, J. H. : Validation of Nakamura's system for the microscopic growth of Mycobacterium lepraemurium. Leprosy Scientific Memoranda, L-531/1, 1974 .

4) Yoshir, Z. and Nakamura, M. : Scanning electron microscopy of Mycobacterium lepraemurium cultivated on the slide glass. Proc. Jap. Acad., 49, 47-50, 1973.

5 ) Yoshil, Z. and NaKamura, M. : Scanning electron microscopic studies on the growth features of Mycobacterium lepraemurium in cell-free medium. J. Gen. Microbiol., 83, 145-152, 1974.

6 ) Nakamura, M., Iтон, T. and Yoshin, Z. : A mode of the growth of Mycobacterium lepraemurium in a cell-free liquid medium. Proc. Soc. Exp. Biol. and Med, 148, 183-186, 1975. 